\title{
Enzymatic Synthesis of Isopropyl Acetate by Immobilized Bacillus cereus Lipase in Organic Medium
}

\author{
Madan Lal Verma, ${ }^{1,2}$ Wamik Azmi, ${ }^{1}$ and Shamsher Singh Kanwar1 \\ ${ }^{1}$ Department of Biotechnology, Himachal Pradesh University, Shimla 171 005, India \\ ${ }^{2}$ Department of Biotechnology, National Institute of Technology, Jalandhar 144 011, India \\ Correspondence should be addressed to Shamsher Singh Kanwar, kanwarss2000@yahoo.com
}

Received 28 October 2010; Accepted 16 February 2011

Academic Editor: Alane Beatriz Vermelho

Copyright ( 2011 Madan Lal Verma et al. This is an open access article distributed under the Creative Commons Attribution License, which permits unrestricted use, distribution, and reproduction in any medium, provided the original work is properly cited.

\begin{abstract}
Selective production of fragrance fatty acid ester from isopropanol and acetic acid has been achieved using silica-immobilized lipase of Bacillus cereus MTCC 8372. A purified thermoalkalophilic extracellular lipase was immobilized by adsorption onto the silica. The effects of various parameters like molar ratio of substrates (isopropanol and acetic acid; 25 to $100 \mathrm{mM}$ ), concentration of biocatalyst $(25-125 \mathrm{mg} / \mathrm{mL})$, reaction time, reaction temperature, organic solvents, molecular sieves, and initial water activity were studied for optimal ester synthesis. Under optimized conditions, $66.0 \mathrm{mM}$ of isopropyl acetate was produced when isopropanol and acetic acid were used at $100 \mathrm{mM}: 75 \mathrm{mM}$ in $9 \mathrm{~h}$ at $55^{\circ} \mathrm{C}$ in $n$-heptane under continuous shaking (160 rpm) using bound lipase $(25 \mathrm{mg})$. Addition of molecular sieves $(3 \AA \times 1.5 \mathrm{~mm})$ resulted in a marked increase in ester synthesis $(73.0 \mathrm{mM})$. Ester synthesis was enhanced by water activity associated with pre-equilibrated saturated salt solution of LiCl. The immobilized lipase retained more than $50 \%$ of its activity after the 6 th cycle of reuse.
\end{abstract}

\section{Introduction}

Environment-friendly biocatalysts are now rapidly substituting the conventional harsh chemical methods for the synthesis of important fatty acid esters used in many chemicals, medicines, cosmetics, and foods [1-5]. The attention towards tremendous use of microbial lipase (triacylglycerol acylhydrolase, EC 3.1.1.3) was exploited in the past decade leading to the easy hydrolysis/synthesis of esters at ambient condition with an advantage of precise selectivity. Such reactions mediated by biocatalysts have advantages like mild reaction conditions, one step synthesis without protection and deprotection steps, and easy application to food processing [6-8]. A lipase catalyzes a reversible reaction and the direction and equilibrium of the reaction is determined by the activities of the substrates, products, temperature, and pressure [9].

Enzymes immobilization is the inherent advantage to isolate the biocatalyst from the reaction product and reuse it in order to increase the process productivity [10-12]. Immobilization by adsorption has been most widely used for immobilization of various enzymes [13, 14]. Highly porous inorganic matrices such as silica aerogels with differing balances of hydrophobic and hydrophilic functionalities have been successfully used for the immobilization of enzymes. Silica aerogels can be considered as "solid" solvent for the enzymes that are able to provide hydrophobic/hydrophilic characteristics differing from those prevailing in the liquid surrounding the aerogels [15].

Esters are a major group of aroma compounds $[16,17]$. This ester possesses fruity odor and is used as artificial flavorings and fragrances. Isopropyl acetate is a solvent used in a variety of manufacturing processes. The present study is focused on the effect of various parameters on silicaimmobilized lipase-catalyzed synthesis of isopropyl acetate in $n$-heptane (Scheme 1) as a model system for the study of esterification. 


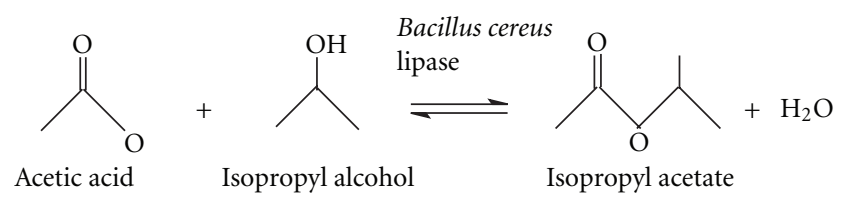

Scheme 1: Isopropyl acetate synthesis using silica bound lipase in $n$-heptane.

\section{Materials and Methods}

2.1. Chemicals and Reagents. $\mathrm{NaNO}_{3}, \mathrm{~K}_{2} \mathrm{HPO}_{4}, \mathrm{KCl}$, $\mathrm{MgSO}_{4} \cdot 7 \mathrm{H}_{2} \mathrm{O}, \mathrm{FeSO}_{4} \cdot 7 \mathrm{H}_{2} \mathrm{O}$, and $\left(\mathrm{NH}_{4}\right)_{2} \mathrm{SO}_{4}$ (S.d. FineChem, Mumbai); yeast extract and gum acacia (HIMEDIA Laboratory, Mumbai); $p$-nitrophenyl palmitate ( $p$-NPP) alkanes (n-pentane, $n$-hexane, $n$-heptane, $n$-nonane, $n$-hexadecane and $n$-heptadecane), and silica gel 60 (0.040$0.063 \mathrm{~mm}, 230-400 \mathrm{mesh})$ were from Lancaster Synthesis, England; Glacial acetic acid; Triton X-100 (Qualigens Fine Chemicals, India); isopropyl acetate was obtained from Acros Organics (New Jersey, USA); LiCl, KI, $\mathrm{KNO}_{3}$, sucrose, isopropanol, and molecular sieve $(3 \AA \dot{x} \times 1.5 \mathrm{~mm})$ were procured from E. Merck Pvt. Ltd., Mumbai, India. All chemicals were of analytical grade and were used as received.

\subsection{Microorganism and Lipase. Bacillus cereus MTCC 8372} was originally isolated from a soil sample by selective enrichment technique at $55^{\circ} \mathrm{C}$. The culture was maintained by repeated subculturing on a mineral-based $(\mathrm{MB})$ medium supplemented with $1 \%(\mathrm{v} / \mathrm{v})$ cotton seed oil (as a sole Csource). The MB broth contained (g/L); $\mathrm{NaNO}_{3} 3 ; \mathrm{K}_{2} \mathrm{HPO}_{4}$ $0.1 ; \mathrm{MgSO}_{4} \cdot 7 \mathrm{H}_{2} \mathrm{O} 0.5 ; \mathrm{KCl} 0.5, \mathrm{FeSO}_{4} \cdot 7 \mathrm{H}_{2} \mathrm{O} 0.01$, and yeast extract $4.0, \mathrm{pH} 7.5 \pm 0.1$.

2.3. Production of Lipase by B. cereus. Seed culture of B. cereus was prepared by inoculating $50 \mathrm{~mL}$ of broth with a loop full of culture. The culture was allowed to grow for $36 \mathrm{~h}$ at $55^{\circ} \mathrm{C}$ under continuous shaking at $160 \mathrm{rpm}$. Thereafter, $10 \%(\mathrm{v} / \mathrm{v})$ of $36 \mathrm{~h}$ old seed culture was used to inoculate $1000 \mathrm{~mL}$ of the production medium $(50 \mathrm{~mL}$ each in $250 \mathrm{~mL}$ capacity Erlenmeyer flasks). The seeded production medium was incubated at $55^{\circ} \mathrm{C}$ and $160 \mathrm{rpm}$ for $48 \mathrm{~h}$ (Orbitek shaking incubator, AID Electronics, Chennai, India).

2.4. Purification of B. cereus Lipase. The culture broth was centrifuged after $48 \mathrm{~h}$ post inoculation at $10,000 \times \mathrm{g}$ for $10 \mathrm{~min}$ at $4^{\circ} \mathrm{C}$ (SIGMA $3 \mathrm{~K} 30$, Germany). The cell pellet was discarded and the supernatant was filtered through Whattman no. 1. The protein content was measured [18]. Henceforth, this filtrate broth was referre to as crude lipase. The required amount of ammonium sulfate was added to the crude lipase to achieve $80 \%(\mathrm{w} / \mathrm{v})$ saturation. The contents were mixed thoroughly and kept over night at $4^{\circ} \mathrm{C}$. The precipitates sedimented by centrifugation at $12,000 \times \mathrm{g}$ at $4^{\circ} \mathrm{C}$ for $30 \mathrm{~min}$ were reconstituted in minimum amount of Tris buffer $(0.05 \mathrm{M}, \mathrm{pH} 8.5)$ and were extensively dialyzed against the same buffer. The purification of the dialyzed lipase enzyme was performed on an Octyl-Sepharose column (Amersham Pharmacia, Sweden) [19]. The fractions were analyzed for lipase activity and protein. The active fractions showing lipase activity were pooled and stored at $-20^{\circ} \mathrm{C}$. The specific activity of the purified enzyme was compared with the crude enzyme and fold purification was calculated.

2.5. Determination of Lipase Activity. The lipase was assayed by a colorimetric method using $p$-NPP [20]. The reaction mixture contained $80 \mu \mathrm{L}$ of $p$-NPP stock solution $(20 \mathrm{mM} p$ NPP prepared in isopropanol), $20 \mu \mathrm{L}$ of test sample (lipase) and Tris buffer $(0.05 \mathrm{M}, \mathrm{pH} 8.5)$ to make final volume to $3.0 \mathrm{~mL}$. The reaction mixture was incubated at $55^{\circ} \mathrm{C}$ for $10 \mathrm{~min}$ in a water bath, and lipase activity was assayed at $410 \mathrm{~nm}$. Chilling at $-20^{\circ} \mathrm{C}$ for $7 \mathrm{~min}$ was employed to stop the reaction. One unit (IU) of lipase activity was defined as micromole(s) of $p$-nitrophenol released per minute by hydrolysis of $p$-NPP by one $\mathrm{mL}$ of soluble enzyme or $1 \mathrm{~g}$ of matrix bound enzyme at $55^{\circ} \mathrm{C}$ (weight of matrix included) under assay conditions.

2.6. Immobilization of Purified Bacterial Lipase on Matrix Silica. The purified lipase from B. cereus was immobilized on silica gel 60. The matrix was first washed with distilled water (thrice) followed by Tris buffer $(0.05 \mathrm{M}, \mathrm{pH} 8.5)$ before immobilization. Approximately, $4 \mathrm{~mL}(\sim 0.82 \mathrm{IU})$ of the purified enzyme was then added to silica $(1 \mathrm{~g})$, and the suspension was incubated for $1 \mathrm{~h}$ at $37^{\circ} \mathrm{C}$ in a glass vial. The unbound lipase was removed by five washings with Tris buffer (0.05 M, pH 8.5). Finally, immobilized matrices were kept suspended in Tris buffer at $4^{\circ} \mathrm{C}$ till further use. In each of the assays, $20 \mathrm{mg}$ immobilized enzyme preparation (matrix) was used. The volume of the supernatant, unbound protein and lipase activity were estimated using standard methods. The bound protein in matrix was determined by subtracting unbound protein in the supernatant from the total protein used for immobilization.

2.6.1. Esterification Studies for Isopropyl Acetate Synthesis Using Silica-Immobilized Lipase. A reference profile was prepared using varying concentrations of isopropyl acetate (20$100 \mathrm{mmol} / \mathrm{L}$ ) in $n$-heptane (retention time $0.91 \mathrm{~min}$ ). The reference curve was plotted between the molar concentration $(\mathrm{mmol} / \mathrm{L})$ of isopropyl acetate and the corresponding area under the peak. The retention time for isopropanol and acetic acid is $0.79 \mathrm{~min}$ and $1.03 \mathrm{~min}$, respectively.

2.6.2. Analysis of Isopropyl Acetate Synthesis by Gas Liquid Chromatography (GLC). The sample size for the GLC analysis was $2 \mu \mathrm{L}$. The sample was analyzed with GLC using a packed column (10\% SE-30 Chrom WHP, 2-meter length, mesh size 80-100, internal diameter 1/8 inches, Netel Chromatograph, Thane, India). Nitrogen was used as a carrier gas $\left(30 \mathrm{~cm}^{3} / \mathrm{min}\right)$. GLC was programmed for oven temperature $75-125^{\circ} \mathrm{C}$, ramp rate $25^{\circ} \mathrm{C} \mathrm{min}^{-1}$, injector temperature $135^{\circ} \mathrm{C}$, FID temperature $145^{\circ} \mathrm{C}$, and holding time $2 \mathrm{~min}$ at $125^{\circ} \mathrm{C}$. 
2.6.3. Effect of Amount of Biocatalyst on Ester Synthesis. The synthesis of isopropyl acetate was studied by taking different amount of immobilized lipase (25-125 mg/reaction volume) in $2.0 \mathrm{~mL}$ of reaction mixture containing $100 \mathrm{mM}$ and $75 \mathrm{mM}$ each of isopropanol and acetic acid in $n$-heptane at $55^{\circ} \mathrm{C}$ in $9 \mathrm{~h}$ under shaking $(160 \mathrm{rpm})$.

2.6.4. Effect of Relative Molar Concentrations of Reactants on Isopropyl Acetate Synthesis. It was studied by keeping the concentration of one of the reactants (isopropanol or acetic acid) at $100 \mathrm{mM}$ and varying the concentration of another reactant $(25-100 \mathrm{mM})$ in the reaction mixture in $n$ heptane. The esterification was carried out for $9 \mathrm{~h}$ at $55^{\circ} \mathrm{C}$ under continuous shaking using silica-bound lipase, and the amount of ester formed was determined by GLC.

2.6.5. Effect of Reaction Time on Synthesis of Isopropyl Acetate. The reaction mixture comprised silica-immobilized lipase, isopropanol $(100 \mathrm{mM})$, and acetic acid $(75 \mathrm{mM})$ in $n$ heptane. The glass vials were incubated at $55^{\circ} \mathrm{C}$ in a water bath incubator shaker for $15 \mathrm{~h}$. At 3-hour intervals, the solvent phase $(2 \mu \mathrm{L})$ was sampled and analyzed by GLC for the presence of isopropyl acetate.

2.6.6. Effect of Temperature on Isopropyl Acetate Synthesis. The effect of temperature $\left(45,55,65\right.$, and $\left.75^{\circ} \mathrm{C}\right)$ on the synthesis of isopropyl acetate was studied. The reaction mixture containing isopropanol $(100 \mathrm{mM})$ and acetic acid $(75 \mathrm{mM})$ in $n$-heptane was catalyzed by silica-immobilized lipase at each of the selected temperatures for $9 \mathrm{~h}$. The amount of ester synthesized was determined by GLC.

2.6.7. Effect of Molecular Sieves on Isopropyl Acetate Synthesis. The molecular sieves $(3 \AA \times 1.5 \mathrm{~mm})$ were added at the concentration from 25 to $150 \mathrm{mg}$ per reaction volume as mentioned above and synthesis of isopropyl acetate in the reaction mixture was determined.

2.6.8. Effect of Solvents (Alkanes) on Synthesis of Isopropyl Acetate. In the reaction mixture, $(2.0 \mathrm{~mL}) n$-heptane that was initially employed as a solvent phase was replaced with $n$-alkanes of varying C-chain length, that is, $n$-pentane, $n$ hexane, $n$-heptane, $n$-octane, $n$-nonane, $n$-hexadecane, and $n$-heptadecane. The silica-bound lipase was added to the reaction mixture, and the reaction was performed for $9 \mathrm{~h}$ at $55^{\circ} \mathrm{C}$. Ester synthesis was determined by GLC.

2.6.9. Repetitive Use of Silica-Immobilized Lipase for Ester Synthesis. This biocatalyst was used to catalyze fresh esterification reaction under optimized conditions. The immobilized lipase with molecular sieves was used for the synthesis of isopropyl acetate in $n$-nonane in a batch reaction up to 8 cycles of $9 \mathrm{~h}$ each at $55^{\circ} \mathrm{C}$. After first use, the biocatalyst was recovered by decanting the reaction mixture and was washed thrice in excess of $n$-nonane. The amount of ester synthesized was monitored after each cycle of esterification.
TABLE 1: Effect of biocatalyst load on synthesis of isopropyl acetate in $n$-heptane by silica-bound lipase. The reaction mixture containing $100 \mathrm{mM}$ isopropanol and $75 \mathrm{mM}$ acetic acid and silicabound biocatalyst in $n$-heptane was incubated at $55^{\circ} \mathrm{C}$ under shaking for $9 \mathrm{~h}$.

\begin{tabular}{lc}
\hline Immobilized enzyme $(\mathrm{mg})$ & Ester synthesis $(\mathrm{mM})$ \\
\hline 25 & $67 \pm 0.01$ \\
50 & $66 \pm 0.01$ \\
75 & $65 \pm 0.02$ \\
100 & $63 \pm 0.01$ \\
125 & $62 \pm 0.02$ \\
\hline
\end{tabular}

2.6.10. Effect of Initial Water Activity $\left(a_{w}\right)$ for Ester Synthesis. The immobilized lipase and the substrates were preequilibrated separately in containers containing different saturated salt solutions; $\mathrm{LiCl}, \mathrm{KI}, \mathrm{KCl}$, and $\mathrm{KNO}_{3}$ with $\mathrm{a}_{\mathrm{w}} \mathrm{s}$ of $0.12,0.689,0.869$, and 0.960 , respectively. The preequilibration process was carried out overnight at $40^{\circ} \mathrm{C}$. The silica-bound lipase was added to the reaction mixture and reaction was performed for $9 \mathrm{~h}$ at $55^{\circ} \mathrm{C}$ without addition of molecular sieves. Ester synthesis was determined by GLC.

2.7. Statistical Analysis. Standard deviation (SD) and standard error of means (SME) were calculated from data obtained for three replicates for each of the parameters studied.

\section{Results and Discussion}

3.1. Protein Binding Efficiency of the Silica Matrix. The purification of microbial lipases using hydrophobic interaction chromatography has been recently well established $[21,22]$. The purified lipase by Octyl-Sepharose column [19] was used for the enzyme immobilization. The silica matrix efficiently bound the enzyme (67\% protein binding). The bound lipase exhibited an activity $2.1 \mathrm{IU} / \mathrm{g}$ matrix (weight of matrix included).

3.2. Effect of Enzyme Concentration on the Isopropyl Acetate Synthesis. Enzyme concentration is known to influence the esterification behavior. Different amounts of bound lipase were used and the progress of the ester synthesis was monitored by GLC. Maximum esterification $(67.0 \pm 0.1 \mathrm{mM})$ was achieved when $25 \mathrm{mg}$ of silica-bound lipase was used (Table 1). However, further increase in the amount of bound lipase failed to further enhance the rate of esterification. An increase in the quantity of biocatalyst concentration resulted in a decrease in the apparent enzyme activity in the production of ethyl acetate to an increase in diffusion limitation, a problem that may be minimized in large-scale experiments by optimal biocatalyst and bioreactor design.

3.3. Effect of Relative Concentration of Reactants on Esterification. At a fixed concentration of acetic acid $(100 \mathrm{mM})$, an increase in the concentration of isopropanol $(25-100 \mathrm{mM})$ at $55^{\circ} \mathrm{C}$ promoted the synthesis of ester $(21.0 \pm 0.2$ to 


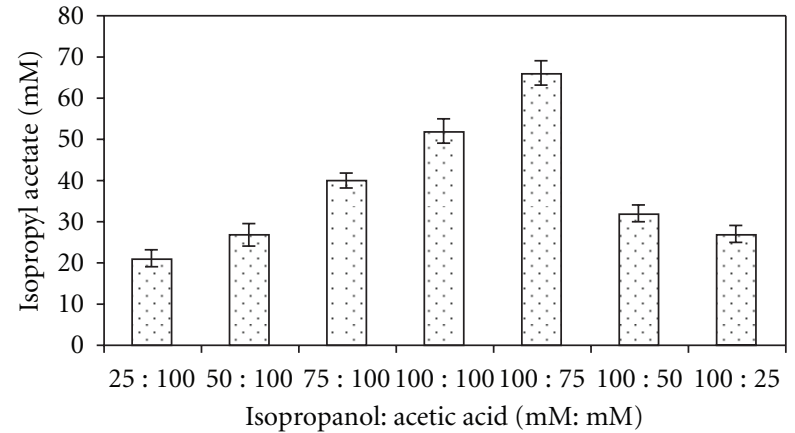

Figure 1: Effect of molar concentrations of reactants on the synthesis of isopropyl acetate. The reaction mixture containing varying ratio of isopropanol and acetic acid in $n$-heptane was incubated at $55^{\circ} \mathrm{C}$ under shaking for $9 \mathrm{~h}$.

$52.0 \pm 0.2 \mathrm{mM})$. However, when the concentration of isopropanol was kept fixed $(100 \mathrm{mM})$, there was a marked increase in ester synthesis $(27.0 \pm 0.1$ to $66.0 \pm 0.1 \mathrm{mM})$. Use of equimolar concentrations of both reactants had deleterious effect on the ester synthesis. It appeared that the ester was optimally synthesized when alcohol and acid were used at $100 \mathrm{mM}$ and $75 \mathrm{mM}$, respectively, in $n$-heptane under continuous shaking for $9 \mathrm{~h}$ at $55^{\circ} \mathrm{C}$ (Figure 1). Thus, in the subsequent reactions, isopropanol and acetic acid were used at $100 \mathrm{mM}$ and $75 \mathrm{mM}$ concentration, respectively.

In a previous study, high concentration of acetic acid (0.4 to $0.7 \mathrm{M}$ ) inhibited SP435 lipase activity resulting in low conversion yields for acetate esters [23]. The presence of fatty acid (acetic) at higher concentration could damage the hydrolytic layer of the enzyme structure causing lipase deactivation during esterification process. Thus, B. cereus MTCC 8372 lipase appeared to be vulnerable to high concentration of acetic acid in reaction medium just like other lipases. Due to toxicity of (acetic) acid in higher concentration on lipase activity in enzymatic acetylation, the use of acids as an acyl donor in transesterification and direct esterification reactions was previously attempted with little or no success $[16,17]$.

3.4. Effect of Reaction Time on Synthesis of Isopropyl Acetate. It was studied at a temperature of $55^{\circ} \mathrm{C}$ in $n$-heptane under continuous shaking (Figure 2) up to $15 \mathrm{~h}$. The synthesis of ester was time dependant, and maximum amount of isopropyl acetate $(66.0 \pm 0.1 \mathrm{mM})$ was produced after $9 \mathrm{~h}$ of reaction when isopropanol and acetic acid were used at $100 \mathrm{mM}$ and $75 \mathrm{mM}$, respectively, in $n$-heptane.

3.5. Effect of Reaction Temperature on the Isopropyl Acetate Synthesis. An increase in temperature of reaction mixture might interfere with the porosity, hydrophobic character and diffusion of the reactants and/or products at the catalytic site of enzyme or hydrogel. The reaction temperature above or below $55^{\circ} \mathrm{C}$ decreased the ester production (Figure 3). This might be on account of denaturation of the lipase as well as alteration in the 3D structure of lipase. Thus, $66.0 \pm 0.2 \mathrm{mM}$

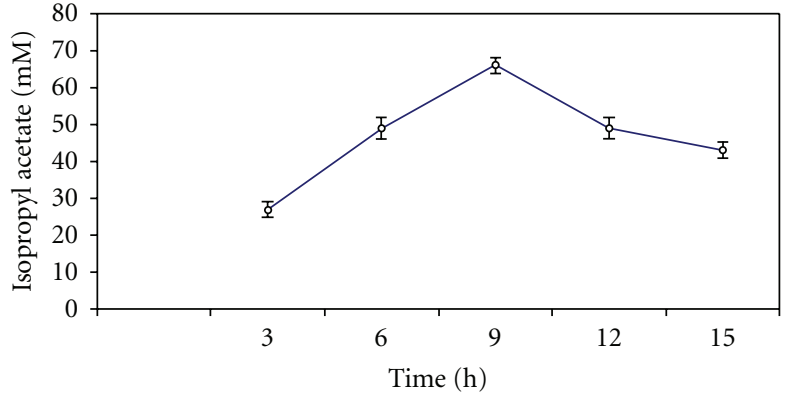

FIGURE 2: Effect of reaction time on the synthesis of isopropyl acetate. The reaction mixture containing $100 \mathrm{mM}$ isopropanol and $75 \mathrm{mM}$ acetic acid and silica-bound biocatalyst in $n$-heptane was incubated at $55^{\circ} \mathrm{C}$ under shaking.

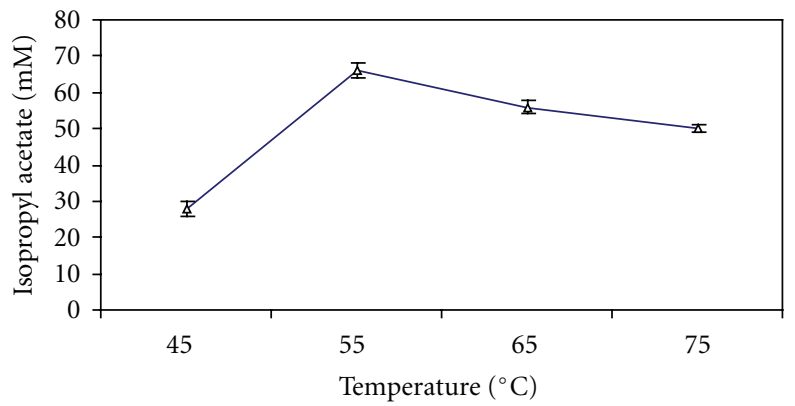

Figure 3: Effect of reaction temperature on the synthesis of isopropyl acetate. The reaction mixture containing $100 \mathrm{mM}$ isopropanaol and $75 \mathrm{mM}$ acetic acid, and silica-bound biocatalyst in $n$-heptane was incubated at stated temperature under shaking for $9 \mathrm{~h}$.

of isopropyl acetate synthesis was achieved at $55^{\circ} \mathrm{C}$ in $9 \mathrm{~h}$ in a batch reaction.

It appeared that temperature has an important effect on the physical state of substrate dispersion in an organic solvent. Higher temperature and liquefaction can be assumed to make the substrate more acceptable for the enzyme. Moreover, immobilization facilitated dispersal of enzyme on a solid surface to provide far greater interfacial area and accessibility of substrate relative to the use of enzyme powders in low water reaction media [24].

3.6. Effect of Solvents (n-Alkanes) on the Ester Synthesis. The choice of an appropriate solvent system that keeps the reactants dissolved and did not interact with the enzyme, matrix/support, or any of the reactants is very important in achieving efficient esterification. Uses of $n$-octane or $n$ nonane have nearly similar effect on the amount of ester formed under similar conditions. The maximum conversion of reactants into ester was recorded in $n$-nonane $(67.0 \pm$ $0.2 \mathrm{mM}$ ) at $55^{\circ} \mathrm{C}$. There is an increase in ester synthesis from $n$-pentane $(39.0 \pm 0.2 \mathrm{mM})$ to $n$-nonane $(67.0 \pm 0.2 \mathrm{mM})$ followed decrease in ester synthesis from $n$-hexadecane (53.0 $\pm 0.3 \mathrm{mM})$ to $n$-heptadecane $(57.0 \pm 0.1 \mathrm{mM})$. Among various $n$-alkanes, $n$-nonane was considered best for ester synthesis in a water-free system (Figure 4). 


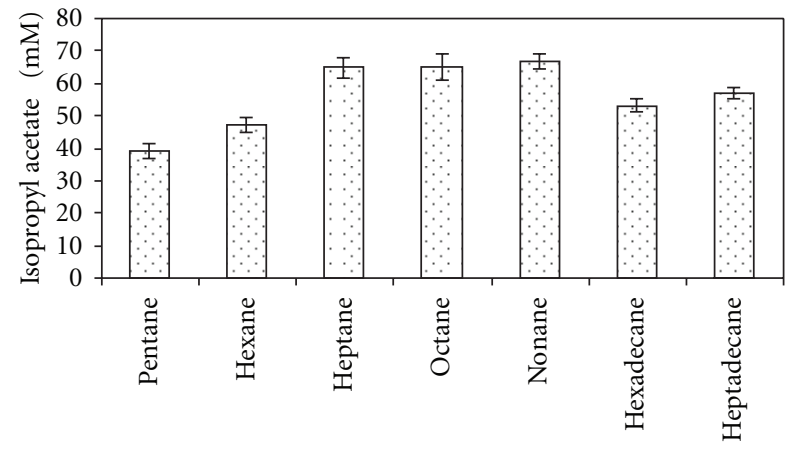

Choice of alkanes

FIGURE 4: Effect of solvents ( $n$-alkanes) on the synthesis of isopropyl acetate. using silica bound lipase. The reaction mixture containing $100 \mathrm{mM}$ isopropanol and $75 \mathrm{mM}$ acetic acid and silica-bound biocatalyst in stated $n$-alkanes was incubated at $55^{\circ} \mathrm{C}$ temperature under shaking for $9 \mathrm{~h}$.

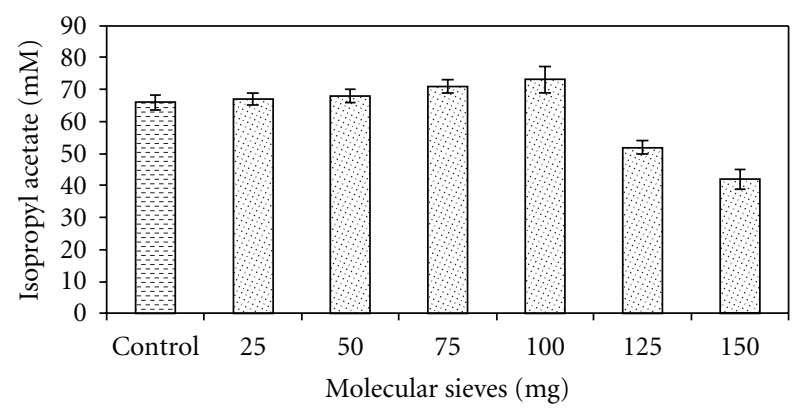

FIGURE 5: Effect of molecular sieves $(3 \AA \AA \times 1.5 \mathrm{~mm})$ on the synthesis of isopropyl acetate. A control was also maintained (without molecular sieves) for performing esterification. The reaction mixture containing $100 \mathrm{mM}$ isopropanol and $75 \mathrm{mM}$ acetic acid and silicabound biocatalyst in $n$-heptane was incubated at $55^{\circ} \mathrm{C}$ temperature under shaking for $9 \mathrm{~h}$.

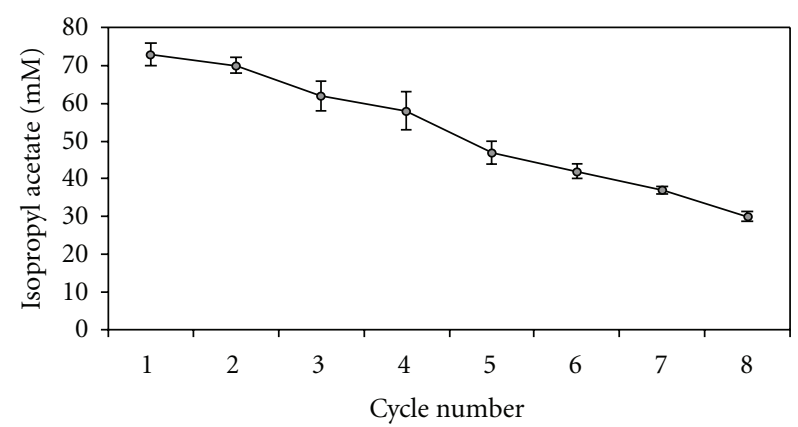

FIgURE 6: Reusability studies using silica immobilized lipase for ester synthesis. The silica-bound lipase with optimised molecular sieves at $55^{\circ} \mathrm{C}$ was used to achieve esterification of isopropanol $(100 \mathrm{mM})$ and acetic acid $(75 \mathrm{mM})$ in $n$-heptane at $55^{\circ} \mathrm{C}$ in repetitive cycles of $9 \mathrm{~h}$ each under shaking.
TABLe 2: Effect of initial water activity of saturated salt solutions on synthesis of isopropyl acetate. The reaction mixture containing $100 \mathrm{mM}$ isopropanol and $75 \mathrm{mM}$ acetic acid and silica-bound biocatalyst in $n$-heptane was incubated at $55^{\circ} \mathrm{C}$ under shaking for $9 \mathrm{~h}$.

\begin{tabular}{lc}
\hline Salt solutions & Ester synthesis $(\mathrm{mM})$ \\
\hline Control & $66 \pm 0.02$ \\
$\mathrm{LiCl}$ & $72 \pm 0.01$ \\
$\mathrm{KI}$ & $63 \pm 0.02$ \\
$\mathrm{KCl}$ & $58 \pm 0.01$ \\
$\mathrm{KNO}_{3}$ & $52 \pm 0.01$ \\
\hline
\end{tabular}

As an $n$-alkane with a lower or a higher C-chain than $n$ nonane was used as a reaction medium, a gradual decrease in rate of isopropyl acetate synthesis was noticed. As the $\log P$ value of an $n$-alkane decreased corresponding to decrease in the C-chain length of the alkanes, the hydrophobicity of the alkanes, that is, alkanes also decreased in that order [25].

3.7. Effect of Molecular Sieves on Isopropyl Acetate Synthesis. The esterification reaction results in formation of water as a by-product of the reaction, and its removal using molecular sieves might enhance the synthesis of ester by pushing the reaction equilibrium in the forward direction $[26,27]$. However, when the effect of the presence of a molecular sieve was studied by adding molecular sieve at concentrations of 25 to $150 \mathrm{mg}$ per reaction volume, a gradual increase in the synthesis of isopropyl acetate was noticed up to $100 \mathrm{mg}(73.0 \pm 0.2 \mathrm{mM})$, and any further increase in the amount of molecular sieves resulted in a decrease (Figure 5). Esterification markedly increased in the presence of molecular sieves in the present study.

3.8. Repetitive Esterification by Bound Lipase in a Batch Reaction. The silica-bound lipase when repetitively used to perform esterification under optimized conditions $(25 \mathrm{mg}$ immobilized lipase, $55^{\circ} \mathrm{C}$ reaction temperature, $9 \mathrm{~h}$ reaction time, $100 \mathrm{mg}$ molecular sieves) in $n$-nonane resulted in 30 $\pm 0.2 \mathrm{mM}$ isopropyl acetate after 8 th cycle of esterification (Figure 6). The decrease in the yield of the synthesis of ester may be due to a leakage of enzyme to the reaction medium.

3.9. Effect of Initial Water Activity $\left(a_{w}\right)$. Generally, all lipases showed an increase in ester synthesis as $a_{w}$ increased until an optimum $\mathrm{a}_{\mathrm{w}}[28]$, whereby thereafter the ester synthesis decreased as the $a_{w}$ further increased (Table 2). At saturated salt solutions of $\mathrm{LiCl}$, there was maximum ester synthesis $(72.0 \pm 0.1 \mathrm{mM})$ that was however lower that the isopropyl acetate was produced without the use of any of the salts for choosing the $\mathrm{a}_{\mathrm{w}}$. Effect of each of the chosen water activities except $\mathrm{LiCl}$ was inhibitory in the isopropyl acetate synthesis. Water layer is essential for hydrolytic enzyme activity. It maintains the proper catalytic conformation of the lipase enzyme. These results suggest that, at these water activity values, enzymes are fully hydrated (too much water), and thus the enzyme is rendered to have less rigidity and therefore conversion rate diminishes. 
In the present study, we have shown that a systematic approach could be devised on the basis of optimization of reaction parameters and solvent engineering to obtain optimal synthesis of an ester of interest. Maximum conversion for ester synthesis was $97 \%(73 \mathrm{mM})$ recorded. Isopropyl acetate was successfully synthesized by lipasecatalyzed esterification in a short time of $9 \mathrm{~h}$ at $55^{\circ} \mathrm{C}$ in $n$-heptane under continuous shaking ( $160 \mathrm{rpm})$ using bound lipase $(25 \mathrm{mg})$. The immobilized enzyme could be repetitively used for 6 cycles with more than $50 \%$ yield of ester.

\section{Acknowledgments}

The authors gratefully acknowledge the Department of Biotechnology, Ministry of Science and Technology, Government of India, New Delhi for providing the fellowship to M. L. Verma during the entire period of doctoral study. The authors also acknowledge the Bioinformatics Centre (Sub-Distributed Information Centre), Himachal Pradesh University, Shimla for providing the internet facility.

\section{References}

[1] R. Sharma, Y. Chisti, and U. C. Banerjee, "Production, purification, characterization, and applications of lipases," Biotechnology Advances, vol. 19, no. 8, pp. 627-662, 2001.

[2] G. D. Haki and S. K. Rakshit, "Developments in industrially important thermostable enzymes: a review," Bioresource Technology, vol. 89, no. 1, pp. 17-34, 2003.

[3] S. W. Chang, J. F. Shaw, K. H. Yang, I. L. Shih, C. H. Hsieh, and C. J. Shieh, "Optimal lipase-catalyzed formation of hexyl laurate," Green Chemistry, vol. 7, no. 7, pp. 547-551, 2005.

[4] F. Hasan, A. A. Shah, and A. Hameed, "Industrial applications of microbial lipases," Enzyme and Microbial Technology, vol. 39, no. 2, pp. 235-251, 2006.

[5] S. S. Kanwar and M. L. Verma, "Lipases," Encyclopedia of Industrial Biotechnology, vol. 5, pp. 1-16, 2010.

[6] J. A. Arcos, M. Bernabé, and C. Otero, "Quantitative enzymatic production of 6-O-acylglucose esters," Biotechnology and Bioengineering, vol. 57, no. 5, pp. 505-509, 1998.

[7] C. Gao, P. Mayon, D. A. MacManus, and E. N. Vulfson, "Novel enzymatic approach to the synthesis of flavonoid glycosides and their esters," Biotechnology and Bioengineering, vol. 71, no. 3, pp. 235-243, 2000.

[8] U. T. Bornscheuer, C. Bessler, R. Srinivas, and S. H. Krishna, "Optimizing lipases and related enzymes for efficient application," Trends in Biotechnology, vol. 20, no. 10, pp. 433-437, 2002.

[9] T. Kobayashi and S. Adachi, "Reaction equilibrium for lipasecatalyzed condensation in organic solvent systems," Biotechnology Letters, vol. 26, no. 19, pp. 1461-1468, 2004.

[10] B. Zou, Y. Hu, D. Yu et al., "Immobilization of porcine pancreatic lipase onto ionic liquid modified mesoporous silica SBA-15," Biochemical Engineering Journal, vol. 53, no. 1, pp. 150-153, 2010.

[11] S. Gao, Y. Wang, W. Wang, G. Luo, and Y. Dai, "Enhancing performance of lipase immobilized on methyl-modified silica aerogels at the adsorption and catalysis processes: effect of cosolvents," Journal of Molecular Catalysis B, vol. 62, no. 3-4, pp. 218-224, 2010.

[12] T. Itoh, R. Ishii, S. I. Matsuura et al., "Enhancement in thermal stability and resistance to denaturants of lipase encapsulated in mesoporous silica with alkyltrimethylammonium (CTAB)," Colloids and Surfaces B, vol. 75, no. 2, pp. 478-482, 2010.

[13] A. Chaubey, R. Parshad, P. Gupta et al., "Arthrobacter sp. lipase immobilization for preparation of enantiopure masked $\beta$-amino alcohols," Bioorganic and Medicinal Chemistry, vol. 17, no. 1, pp. 29-34, 2009.

[14] E. Yilmaz, K. Can, M. Sezgin, and M. Yilmaz, "Immobilization of Candida rugosa lipase on glass beads for enantioselective hydrolysis of racemic Naproxen methyl ester," Bioresource Technology, vol. 102, no. 2, pp. 499-506, 2011.

[15] U. H. Zaidan, M. B. A. Rahman, M. Basri, S. S. Othman, R. N. Z. R. A. Rahman, and A. B. Salleh, "Silylation of mica for lipase immobilization as biocatalysts in esterification," Applied Clay Science, vol. 47, no. 3-4, pp. 276-282, 2010.

[16] M. L. Verma and S. S. Kanwar, "Properties and application of poly(methacrylic acid-co-dodecyl methacrylate-cl$\mathrm{N}, \mathrm{N}$-methylene bisacrylamide) hydrogel immobilized Bacillus cereus MTCC 8372 lipase for the synthesis of geranyl acetate," Journal of Applied Polymer Science, vol. 110, no. 2, pp. 837-846, 2008.

[17] E. T. Liaw and K. J. Liu, "Synthesis of terpinyl acetate by lipase-catalyzed esterification in supercritical carbon dioxide," Bioresource Technology, vol. 101, no. 10, pp. 3320-3324, 2010.

[18] M. M. Bradford, "A rapid and sensitive method for the quantitation of microgram quantities of protein utilizing the principle of protein dye binding," Analytical Biochemistry, vol. 72, no. 1-2, pp. 248-254, 1976.

[19] M. L. Verma and S. S. Kanwar, "Purification and characterization of a low molecular mass alkaliphilic lipase of Bacillus cereus MTCC 8372," Acta Microbiologica et Immunologica Hungarica, vol. 57, no. 3, pp. 191-207, 2010.

[20] U. K. Winkler and M. Stuckmann, "Glycogen, hyaluronate, and some other polysaccharides greatly enhance the formation of exolipase by Serratia marcescens," Journal of Bacteriology, vol. 138, no. 3, pp. 663-670, 1979.

[21] D. S. Dheeman, G. T. M. Henehan, and J. M. Frías, "Purification and properties of Amycolatopsis mediterranei DSM 43304 lipase and its potential in flavour ester synthesis," Bioresource Technology, vol. 102, no. 3, pp. 3373-3379, 2011.

[22] E. H. Ahmed, T. Raghavendra, and D. Madamwar, "An alkaline lipase from organic solvent tolerant Acinetobacter sp. EH28: application for ethyl caprylate synthesis," Bioresource Technology, vol. 101, no. 10, pp. 3628-3634, 2010.

[23] P. A. Claon and C. C. Akoh, "Effect of reaction parameters on SP435 lipase-catalyzed synthesis of citronellyl acetate in organic solvent," Enzyme and Microbial Technology, vol. 16, no. 10, pp. 835-838, 1994.

[24] G. Bell, P. J. Halling, B. D. Moore, J. Partridge, and D. G. Rees, "Biocatalyst behaviour in low-water systems," Trends in Biotechnology, vol. 13, no. 11, pp. 468-473, 1995.

[25] B. S. Lakshmi, P. Kangueane, K. Madhavi, S. Mukut, and P. Gautam, "The effect of hydrophobicity on the interfacial activation of Candida rugosa lipase," Journal of Biochemistry, Molecular Biology and Biophysics, vol. 4, no. 4, pp. 293-298, 2000.

[26] P. J. Halling, "Thermodynamic predictions for biocatalysis in nonconventional media: theory, tests, and recommendations for experimental design and analysis," Enzyme and Microbial Technology, vol. 16, no. 3, pp. 178-206, 1994. 
[27] K. Kuwabara, Y. Watanabe, S. Adachi, K. Nakanishi, and R. Matsuno, "Synthesis of 6-O-unsaturated acyl L-ascorbates by immobilized lipase in acetone in the presence of molecular sieve," Biochemical Engineering Journal, vol. 16, no. 1, pp. 1722, 2003.

[28] A. Harun, M. Basri, M. B. Ahmad, and A. B. Salleh, "Enantioselective esterification reaction using immobilized Candida rugosa lipase on poly(N-vinyl-2-pyrrolidone-co-styrene) hydrogel," Journal of Applied Polymer Science, vol. 92, no. 5, pp. 3381-3386, 2004. 

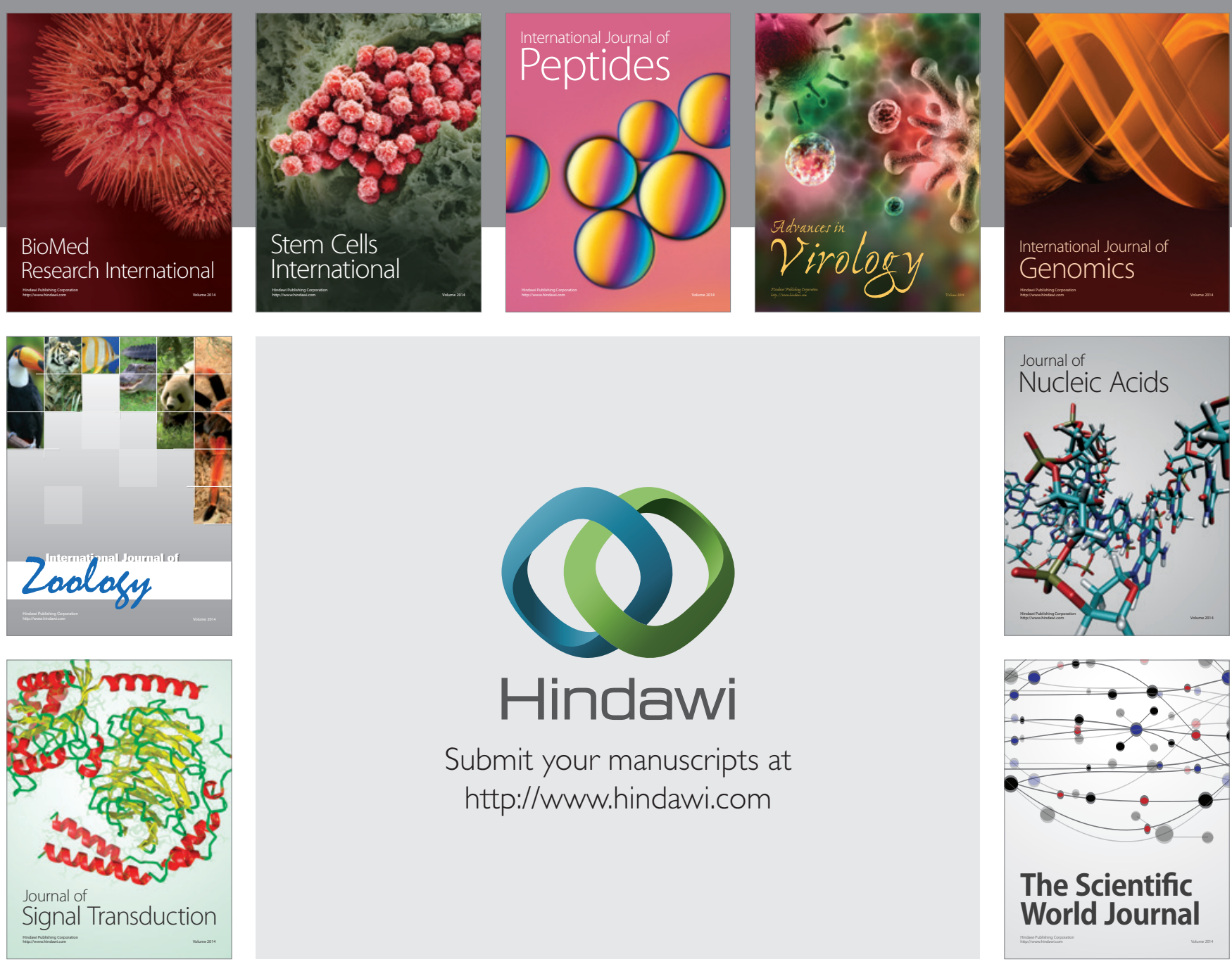

Submit your manuscripts at

http://www.hindawi.com
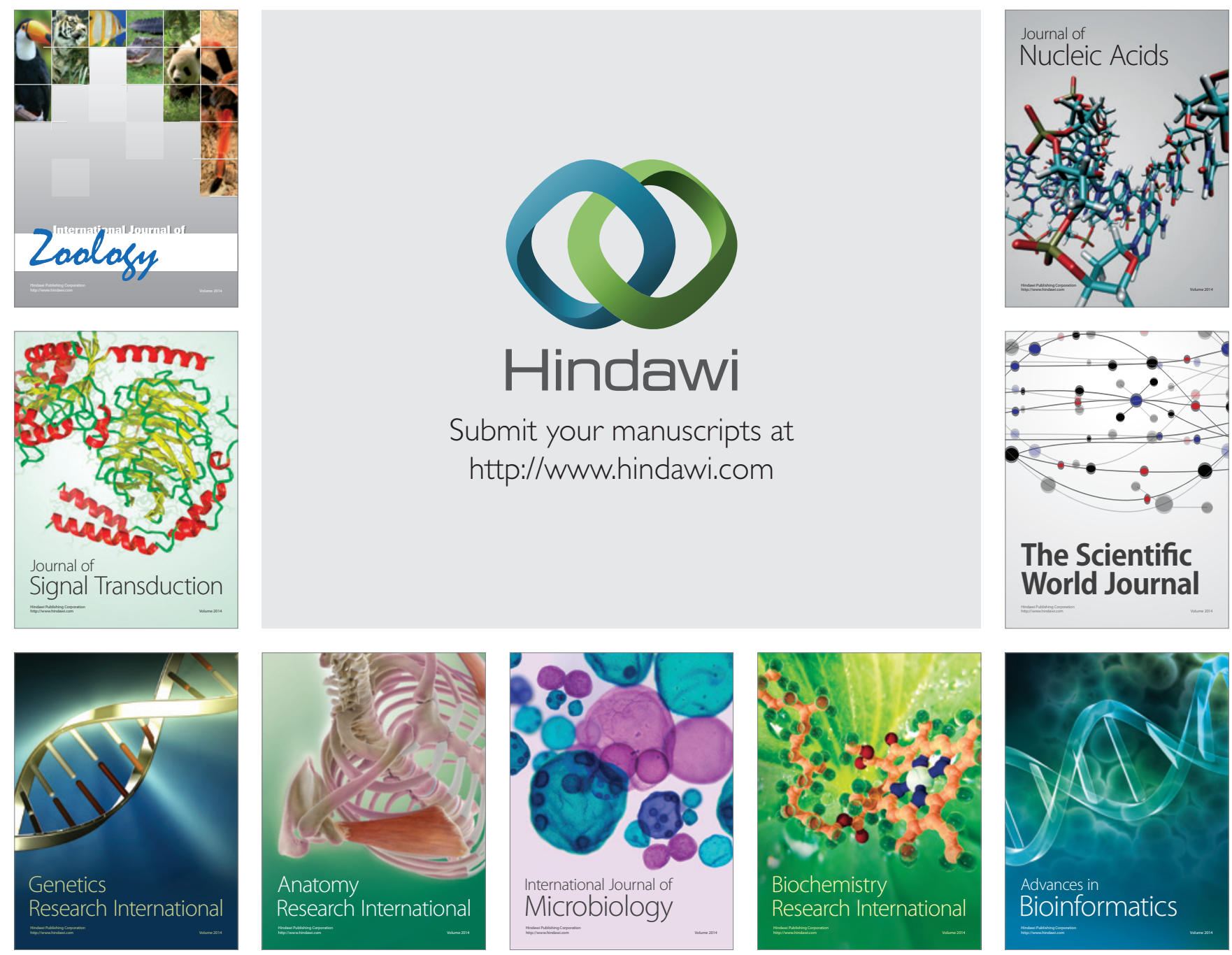

The Scientific World Journal
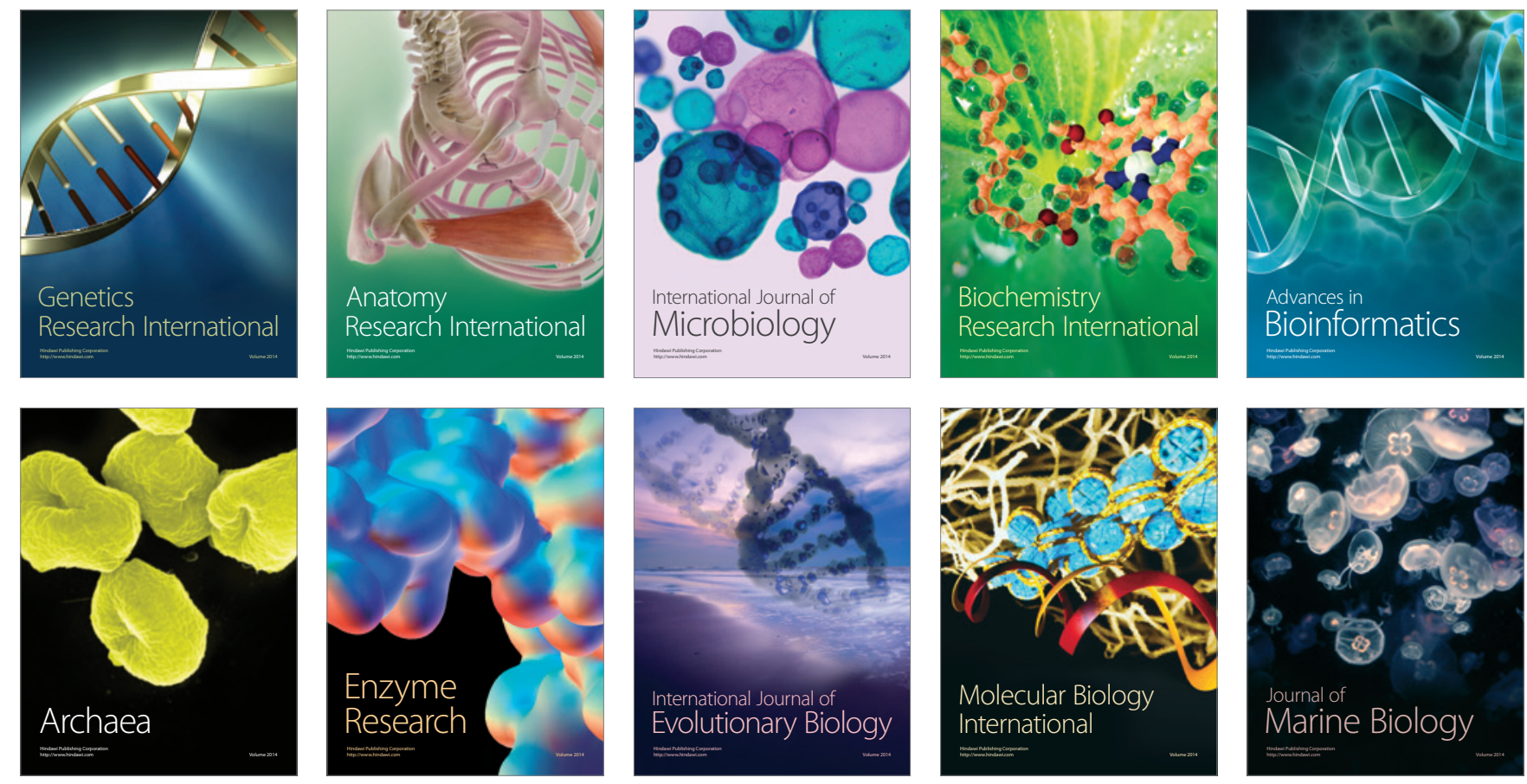